\title{
Invasive giant knotweed (Fallopia sachalinensis) alters the composition of oribatid mite communities
}

\author{
PIOTR SKUBAŁA \\ University of Silesia, Department of Ecology, Bankowa 9, 40-007 Katowice, Poland \\ Corresponding author: piotr.skubala@us.edu.pl
}

(Received on 23 January 2012; Accepted on 24 September 2012)

\begin{abstract}
Plant invasions are a serious global threat to biodiversity and ecosystem stability. The invasive giant knotweed Fallopia sachalinensis (synonym: Reynoutria sachalinensis) is one of the most aggressive plant invaders in many countries. It forms dense stands that prevent other species from growing. To assess the impact of the knotweed, oribatid mite communities were studied under Fallopia-free native vegetation and at Fallopia-infested sites (2 types: $90-100 \%$ and 30\% of coverage) with similar soil. All the sites are located in mixed forest in the Kraków-Częstochowa Upland (Jura Krakowsko-Częstochowska) in south Poland. Species composition and functional group composition of oribatid mite communities were compared. In total, 1540 specimens belonging to 70 oribatid species were collected from 90 soil samples. This successful exotic invasive species had a moderate influence on species richness $(20 \%$ less species at the totally invaded site than at the Fallopia-free site) and a profound effect on soil oribatid mite community composition. Several oribatid species characteristic of a particular site were observed. Shifts were detected in proportions of groups with different habitat specificity (e.g. higher proportion of eurytopic mites at invaded sites), ecomorphological groups (e.g. lower proportion of litter-dwelling mites at invaded sites), trophic groups (e.g. lower proportion of macrophytophagous mites at invaded sites) and zoogeographical groups (e.g. higher proportion of mites with broad geographical distribution at invaded sites). These observations prove the radical negative change of environmental conditions for soil oribatid mites as a result of Fallopia invasion. The increase in sexually reproducing oribatid mites at invaded sites suggests that this way of reproduction is preferable when resources are in shortage.
\end{abstract}

Keywords: knotweed, invasive weed, Oribatida, soil arthropod communities, species diversity, functional group composition

\section{INTRODUCTION}

Over the last 3 decades, invasive alien plants have come to be recognized as one of major threats to biodiversity and ecosystem stability (EHRENFELD 2003). These invaders include knotweeds of the genus Fallopia (synonym Reynoutria). In the $19^{\text {th }}$ century, several knotweed species native to eastern Asia were introduced as ornamental plants into North America and Europe. Fallopia species can be found on the IUCN list of 100 worst invasive alien species, are the second most damaging alien 
plant in Germany, and are among the top 10 invasive plant species in France and the UK (KoutIKA et al. 2011). Once established, Fallopia is highly efficient in resource monopolization and forms highly productive, dense monospecific stands, outcompeting all native plant species (KAPPES et al. 2007).

Successful invaders may alter soil conditions, but the effect of exotic species on soil invertebrates and especially soil mites has been poorly studied (e.g. WARDLE et al. 1995; Belnap \& Phillips 2001; Nicolini \& Topp 2005; Pritekel et al. 2006; St. JoHN et al. 2006). Especially the evaluation of the impact of Fallopia (Reynoutria) species on soil fauna was rarely undertaken (e.g. BEERLING \& DAWAH 1993; KAPPES et al. 2007; Gerber et al. 2008). Skubata \& Mierny (2009) demonstrated the ability of Fallopia sachalinensis to transform native mesofauna communities in the soil. The reduction of abundance of saprophagous mites (Oribatida, Astigmata) and springtails were observed at the totally invaded sites, whereas gamasid and prostigmatid mites benefited from the simplified vegetation structure. The cited authors suggested that antifungal activity of phenolic compounds present in leaves of $F$. sachalinensis negatively influence saprophagous microarthropods.

The primary aim of this project was to explore the effect of giant knotweed (Fallopia sachalinensis) on the composition of oribatid mite communities. The following questions were addressed.

1. Does the presence of Fallopia sachalinensis lower the species richness and diversity of oribatid communities?

2. Do the species composition and the proportions of functional groups in oribatid communities significantly change at sites invaded by the exotic knotweed?

3. Which way of reproduction (sexual or parthenogenetic) is more preferable at a site dominated by the invasive plant?

\section{MATERIAL AND METHODS}

The investigations were undertaken in mixed forest along an educational trail "Dolina Wodącej" in the Kraków-Częstochowa Upland (Jura KrakowskoCzęstochowska) in Silesia Province (south Poland; 50²5’N, $1^{\circ} 40^{\prime} \mathrm{E}$ ). In the forest, 3 adjacent sites were selected, differing in coverage of Fallopia sachalinensis but developed on the same soil. Site I was totally invaded by knotweed, site II was characterized by medium coverage (30\%) of the invader, whereas the control site III was free of Fallopia. At each site, 10 random samples of topsoil $(0-10 \mathrm{~cm}$, including the leaf litter) were taken using a corer of $4.8 \mathrm{~cm}$ in diameter, from a representative quadrat $(10 \mathrm{~m} \times 10 \mathrm{~m})$. Sampling was done seasonally in 2007-2008 (3 times: 2 nd October 2007, 1st March 2008, 5th May 2008), making a total of 30 samples per season. Mites were separated from the soil using the Tullgren funnel.

The analysis of oribatid fauna is based on 1540 specimens of 70 oribatid species (Appendix I). For other information on the sampling sites and methods of collecting mites, see SkubaŁa \& Mierny (2009). Systematics of oribatid mites follows Subias (2004).

Five univariate measures were used to assess community structure: total number of species, number of unique species, mean species number per sample, Shannon 
index of diversity $\left(H^{\prime}\right)$, and evenness index $(J)$. Theoretical total species richness at the studied sites was estimated using $1^{\text {st }}$ order jackknife estimator as well as Chao and Lee richness estimator no. 1. To test the species responding to the presence of Fallopia sachalinensis, a multivariate data analysis - correspondence analysis - was employed. The interpretation was restricted to the ordination space determined by the first 2 axes. To avoid an excessive amount of noise in the data matrix, which could obscure some data features, all species present as singletons were removed from the analysis, because they do not improve the correspondence analysis, and this was confirmed in an initial analysis with all species. The numbers of individuals were log $(\mathrm{x}+1)$ transformed and equal weight was applied to all species. All statistical calculations for this research were done using STATISTICA 10.0 and Species Diversity and Richness IV software. Only adult mites were used in statistical analyses since many groups have polymorphic immature stages that cannot be reliably assigned to any species. Functional group composition (e.g. habitat specificity, ecomorphological, trophic, and zoogeographical groups as well as mode of reproduction) was assessed based on: percentage contributions of mites of each group to the total number of oribatid mites at the given site. Species were assigned to individual groups on the basis of information from many sources (LuXTON 1972; SCHATZ 1983; NorTON et al. 1993; Borcard 1994; Krivolutsky 1995; Subias 2004; Cianciolo \& Norton 2006; WEIGMANN 2006).

\section{RESULTS}

\section{Species richness and diversity of oribatids}

Oribatid species richness (both total number of species and mean species number) was the lowest in the area totally invaded by Fallopia (site I). Nine species less (20\%) were observed at this site in comparison with the control site free of the invader (site III). Species diversity (Shannon index $H^{\prime}$ ) at site I was similar to that observed at site III (no significant differences), whereas the evenness index $(J)$ was significantly higher at the invaded site. It is noteworthy that the highest species richness, diversity, and number of unique species were observed at the site with moderate coverage of Fallopia (site II) (Table 1).

The theoretical number of species in the studied sites was higher for $1^{\text {st }}$ order jackknife estimator, ranging from 50.6 (site I) to 68.4 (site II). In all cases it was only slightly higher than the number of observed species. Species recovery, i.e. difference between the number of collected species and the estimated total species richness varied between $0.9 \%$ and $37 \%$ (both for site III, Chao and Lee richness estimator no. 1) (Table 1).

\section{Species composition of oribatid communities}

Ordination by correspondence analysis was used to assess community similarities and relations between species and communities at sites with different coverage of Fallopia. The eigenvalues (dispersion of the sites/species distribution along the ordination axis) of the first and second axis were $\lambda_{1}=0.321$ and $\lambda_{2}=0.219$, respectively. The first 2 axes cover almost $100 \%$ of the total variance. Fig. 1 shows the gradient 


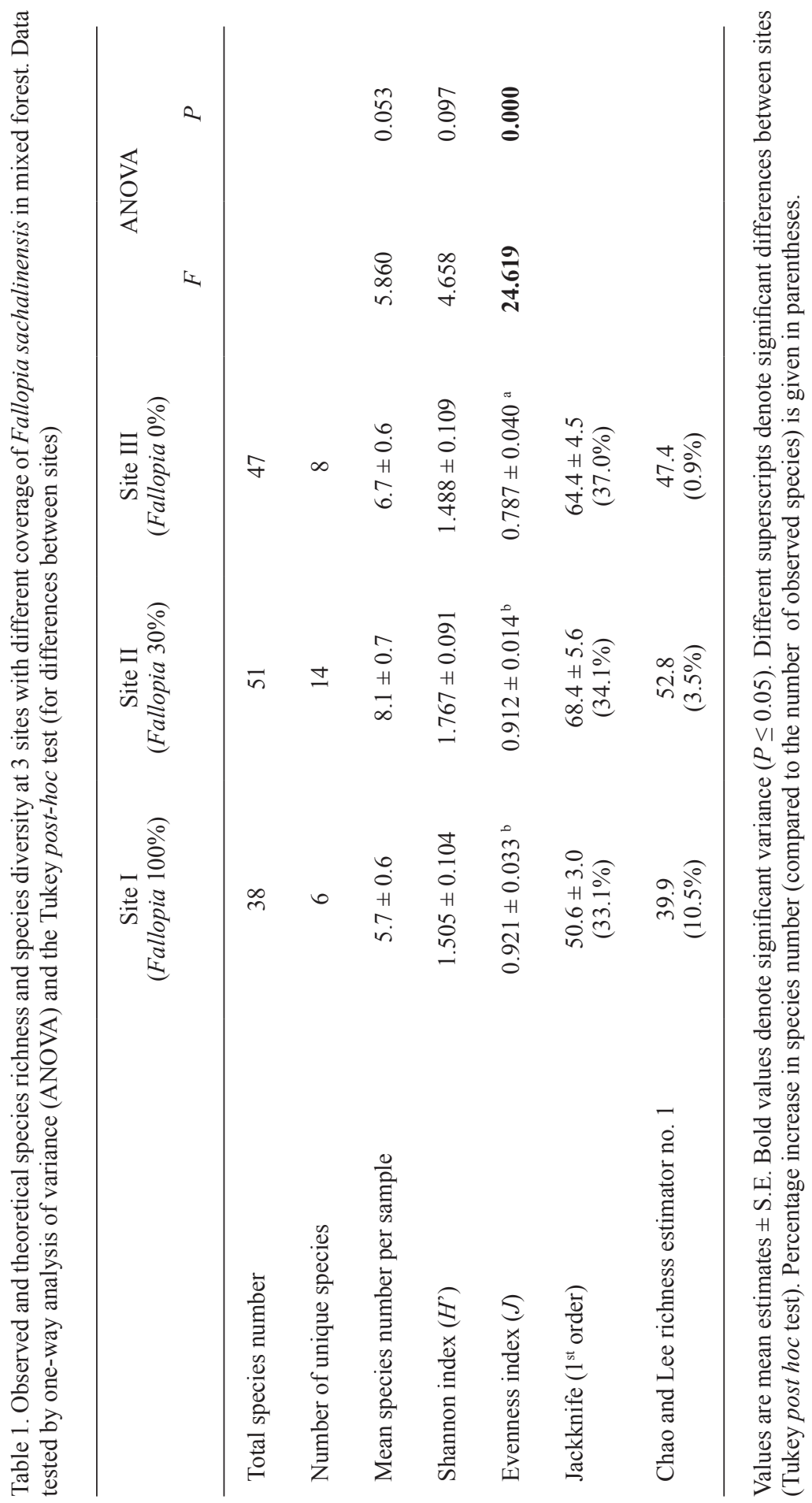


described by axis 1 , which separates the oribatid community of the site with moderate coverage of Fallopia. Axis 2 describes a gradient that separates the oribatid community at the site totally invaded by Fallopia and the control site, free of the invader.

Three dominant oribatid species can be distinguished as associated with the totally invaded site (Fig. 1). Oribatula (O.) tibialis tibialis and Hemileius (H.) initialis are described as eurytopic species, whereas Pergalumna nervosa nervosa occurred mainly in wet peat soils and acid forest soils. All these species feed on higher plant matter as well as fungal material (panphytophages) and have broad distribution ranges (LuXTON 1972; Subias 2004; WeigmanN 2006). For details on ecology, distribution, and other functional characteristics of the species, see Appendix I.

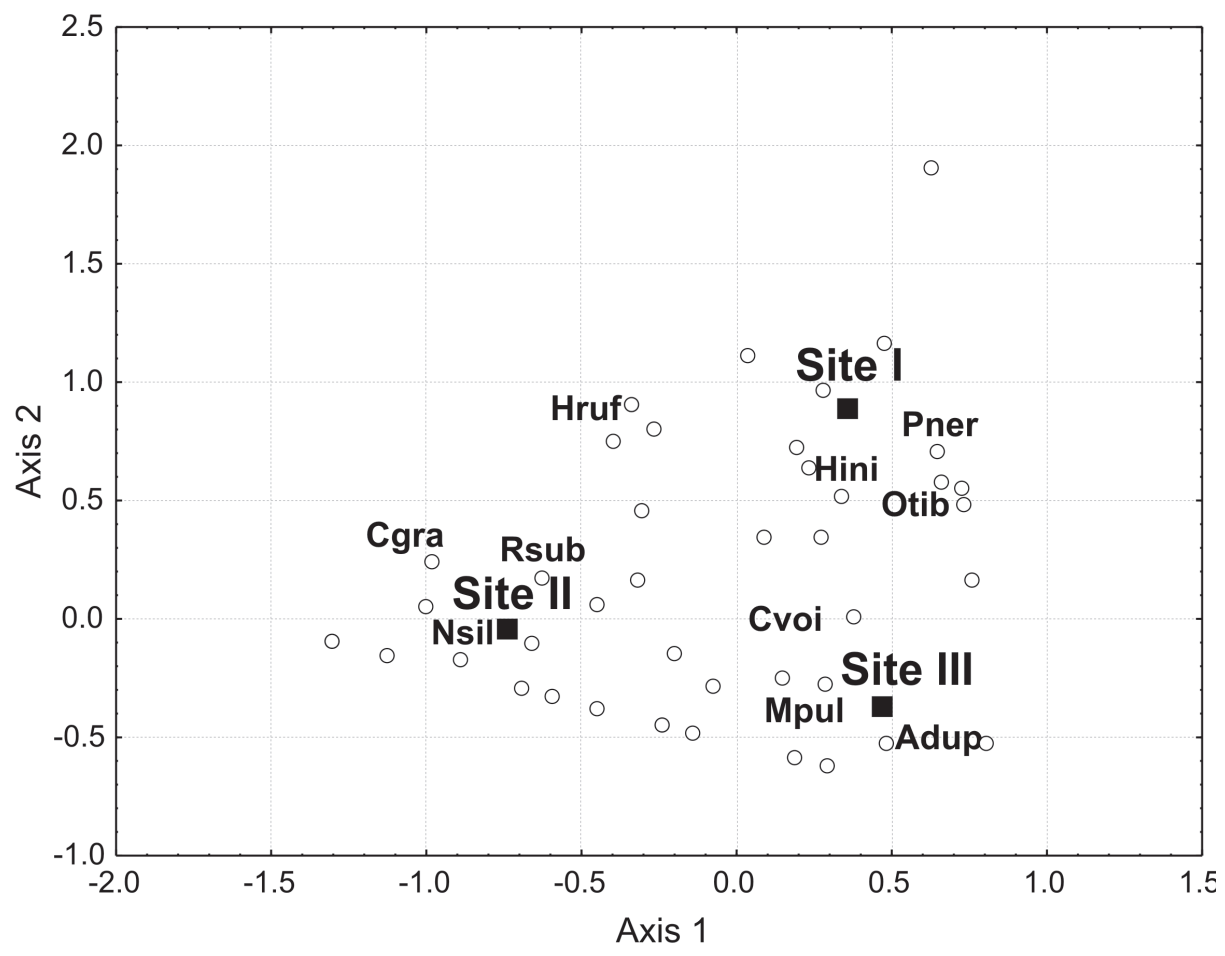

Fig. 1. Biplot of the first 2 axes of correspondence analysis of 48 oribatid species and 3 sampling sites in mixed forest (site I = Fallopia 100\%; site II = Fallopia 30\%; site III = Fallopia 0\%). See Appendix I for full species names of dominants

Rhinoppia subpectinata, Ceratozetes (C.) gracilis, and Nothrus silvestris are typical of the site with a moderate share of Fallopia (Fig. 1). All these species occur in various habitats (eurytopic) and have Holarctic or cosmopolitan distribution. They belong to different feeding groups: microphytophages (R. subpectinata), 
panphytophages (C. gracilis), and macrophytophages ( $N$. silvestris). All dominant species characteristic of the site free of Fallopia are typical forest inhabitants. They also represent the 3 feeding groups mentioned above: microphytophages (Metabelba (M.) pulverulenta), panphytophages (Chamobates (Xiphobates) voigtsi), and macrophytophages (Acrotritia duplicata). The geographical distribution of the species is narrower than that of the species at the invaded sites. One dominant species $-H y$ pochthonius rufulus rufulus - was not unique to any of the studied sites (Fig. 1). It is a eurytopic mite of broad geographical distribution, feeding mainly on fungal hyphae and spores (Luxton 1972; Schatz 1983; Subias 2004; Weigmann 2006).

\section{Functional group composition}

The functional group composition (e.g. habitat specificity, ecomorphological, trophic, and zoogeographical groups as well as the mode of reproduction) in oribatid communities in areas invaded by Fallopia and free of the invader was assessed (Table 2). The Fallopia stands were favoured by eurytopic mites. The proportion of these mites was low at the site free of Fallopia (17.9\% of the total catch at this site) and increased significantly at invaded sites (over 40\%). It is noteworthy that the proportion of oribatids that prefer forest soils was much lower at Fallopia stands ( 50\%) than at site III (over 70\%), but the differences were not significant. The proportion of mites characteristic of open habitats was generally low at all sites.

The Fallopia stands were preferred by surface-dwelling mites. Furthermore, soil-dwelling mites reached a higher proportion at the invaded stands, but the differences were not statistically significant. Proportions of these groups were the lowest at site $\mathrm{C}$. The decline of litter-dwelling mites at invaded sites was another characteristic phenomenon with regard to composition of ecomorphological groups at the studied sites (Table 2). The changes in the proportions of trophic groups in the oribatid communities were also remarkable. The proportion of panphytophagous mites at invaded sites was significantly higher than at site III. Furthermore, a low proportion of macrophytophagous mites at invaded sites in comparison with the control site was observed. As regards zoogeographical groups, no statistically significant differences were noted. However, species with broad zoogeographical distribution dominated at the invaded sites. Palaearctic mites reached the highest proportion in the community at site C. Sexually reproducing mites dominated at invaded sites. Parthenogenetic mites reached a significantly lower proportion at invaded site I $(12.5 \%)$ than at the site free of Fallopia (42.0\%) (Table 2).

\section{DISCUSSION}

The abundance, activity, and composition of decomposer communities have been shown to vary markedly with plant species (BARDGETT et al. 1998; WARDLE et al. 1999). Exotic invasions have been shown to have profound effects on the relationships between plants, soil biota, and ecosystem processes, as the aliens alter decomposition and nutrient cycling (PorAzINSKA et al. 2003; Ashton et al. 2005). In this study a marked influence of Fallopia on species richness, species composition, and functional group composition of oribatid mite communities was observed. 
Table 2. Percentage contributions (and in brackets: species number) of groups with different functional characteristics at 3 sites with different coverage of Fallopia sachalinensis in mixed forest. Differences in mean abundance of mites between sites tested by the Kruskal-Wallis test

\begin{tabular}{|c|c|c|c|c|c|}
\hline \multirow[t]{2}{*}{ Group } & \multirow{2}{*}{$\begin{array}{c}\text { Site I } \\
\text { (Fallopia } 100 \%)\end{array}$} & \multirow{2}{*}{$\begin{array}{c}\text { Site II } \\
\text { (Fallopia } 30 \%)\end{array}$} & \multirow{2}{*}{$\begin{array}{c}\text { Site III } \\
\text { (Fallopia } 0 \%)\end{array}$} & \multicolumn{2}{|c|}{ Kruskal-Wallis test } \\
\hline & & & & $H$ & $P$ \\
\hline \multicolumn{6}{|c|}{ Habitat specificity } \\
\hline Eurytopic & $40.9(10)^{b}$ & $43.5(16)^{\mathrm{b}}$ & $17.9(16)^{\mathrm{a}}$ & 9.284 & 0.010 \\
\hline Forest & $48.2(19)$ & $51.6(27)$ & $75.4(24)$ & 1.334 & 0.513 \\
\hline Open habitat & $5.8(4)$ & $3.2(2)$ & $3.6(5)$ & 2.183 & 0.335 \\
\hline Unknown & $5.1(5)$ & $1.7(6)$ & $3.1(2)$ & & \\
\hline \multicolumn{6}{|c|}{ Ecomorphological groups } \\
\hline Surface-dwelling & $44.0(23)^{b}$ & $49.1(29)^{b}$ & $29.2(29)^{\mathrm{a}}$ & 11.519 & 0.003 \\
\hline Litter-dwelling & $7.4(4)$ & $20.6(5)$ & $38.3(4)$ & 2.889 & 0.235 \\
\hline Soil-dwelling & $10.9(4)$ & $10.7(9)$ & $3.4(6)$ & 4.612 & 0.099 \\
\hline Non-specialized & $37.7(7)$ & $19.6(8)$ & $29.1(8)$ & 3.527 & 0.171 \\
\hline \multicolumn{6}{|c|}{ Trophic groups } \\
\hline Panphytophagous & $63.1(19)^{b}$ & $62.3(26)^{\mathrm{b}}$ & $47.4(26)^{\mathrm{a}}$ & 8.941 & 0.011 \\
\hline Microphytophagous & $28.0(13)$ & $25.1(18)$ & $19.5(17)$ & 4.303 & 0.116 \\
\hline Macrophytophagous & $8.9(6)$ & $12.4(6)$ & $33.1(4)$ & 1.498 & 0.472 \\
\hline Unknown & - & $0.2(1)$ & - & & \\
\hline \multicolumn{6}{|c|}{ Zoogeographical group } \\
\hline Cosmopolitan & $3.5(2)$ & $16.8(3)$ & $2.7(4)$ & 0.544 & 0.761 \\
\hline Semicosmopolitan & $18.7(6)$ & $12.8(7)$ & $9.2(8)$ & 4.530 & 0.103 \\
\hline Holarctic & $40.4(15)$ & $30.4(17)$ & $25.3(18)$ & 4.727 & 0.094 \\
\hline Palaearctic & $32.7(11)$ & $36.8(16)$ & $60.4(14)$ & 3.082 & 0.214 \\
\hline European & $4.3(3)$ & $3.2(8)$ & $2.4(3)$ & 3.061 & 0.216 \\
\hline Unknown & $0.4(1)$ & - & - & & \\
\hline \multicolumn{6}{|c|}{ Reproduction } \\
\hline Sexual & $87.5(33)^{b}$ & $74.5(42)^{b}$ & $58.0(38)^{\mathrm{a}}$ & 15.243 & 0.000 \\
\hline Parthenogenetic & $12.5(5)$ & $25.5(9)$ & $42.0(9)$ & 0.277 & 0.970 \\
\hline
\end{tabular}

Bold values denote significant variance in abundance within rows $(P \leq 0.05)$. Means sharing a superscript ( $\mathrm{a}$ or $\mathrm{b}$ ) do not differ significantly from other means (multiple comparison rank test, $P>0.05)$.

Large-scale invasion by exotic Fallopia affects to some extent the species richness of soil oribatid mites. Overall oribatid species richness at the totally invaded Fallopia site in the studied mixed forest was $20 \%$ lower than in the control area of the forest, free of the invader. However, it is noteworthy that in the area with moderate coverage of Fallopia, oribatids were even more diverse (and the number of unique species was higher) than in the part of the forest free of the invader. Thus it can be concluded that there is a link between the replacement of native plant species by exotic Fallopia and the reduction in overall species richness of oribatids. A similar 
correlation was observed by GERBER et al. (2008) in Fallopia-invaded riparian habitats for macroinvertebrates. The cited authors observed an even higher reduction of invertebrate species richness (40\% and $25 \%$ ) in pitfall traps. Similarly, BeERLING \& DAWAH (1993) found invertebrate species richness to be lower on Fallopia japonica than on sympatric native plant species. On the other hand, DASSONVILLE et al. (2010) found the major groups of mesofauna (springtails, gamasid and oribatid mites) being similar when comparing invaded and control plots. One of the possible reasons of the reduction in oribatid species richness is a reduction of soil organic matter. Lower particulate organic matter weight and $\mathrm{C}$ and $\mathrm{N}$ content were observed by KouTIKA et al. (2007) in plots invaded by Fallopia japonica. As regards other invasive plants, the results are uncertain. BELNAP \& PHILLIPS (2001) observed that the response of oribatid mites to invasion by the grass Bromus tectorum differed between sites. However, ST. JoHN et al. (2006) did not find any evidence that the community composition of soil mites was specific to grass species (native and invasive).

The analysed oribatid communities associated with Fallopia invasion were characterized by changes in species composition and by shifts in the functional group composition. Fallopia caused a few species to increase in abundance, e.g. Oribatula (O.) tibialis tibialis, Hemileius (H.) initialis, Pergalumna nervosa nervosa (species associated with the totally invaded site) as well as Rhinoppia subpectinata, Ceratozetes $(C$.) gracilis, and Nothrus silvestris (species typical of the site moderately covered by the invader). Most species of this group are eurytopic mites feeding on various food sources. Several other species significantly declined at the sites with Fallopia, e.g. Metabelba (M.) pulverulenta, Chamobates (Xiphobates) voigtsi, and Acrotritia duplicata (species typical of the site free of Fallopia). They are forest species belonging to different trophic groups.

The presence of forest species, such as Metabelba (M.) pulverulenta, Chamobates (Xiphobates) voigtsi, and Acrotritia duplicata, a higher proportion of eurytopic mites, and slightly higher proportion of mites typical of open habitats in Fallopia stands prove the radical change of environmental conditions for soil oribatid mites as a result of Fallopia invasion. Topp et al. (2008) reported also on the influence of Fallopia invasion on microclimatic conditions and found a higher abundance of forest ground-dwelling beetles in the Fallopia stands. The cited authors suggested that the Fallopia stand of the ruderal embankment partially mimics that of forest habitats. This was not the case with regard to oribatid mites studied in the present project. The radical change of environmental conditions for oribatids at the Fallopia-invaded sites, especially in the litter layer, is well proven, as the proportion of litter-dwelling mites is reduced significantly at the invaded sites. A shift in the proportions of trophic groups following Fallopia invasion was also observed. The proportion of macrophytophagous mites was significantly lower at the invaded sites. This may suggest that the plant material of Fallopia is much less palatable for oribatid mites than that produced by native plants. The proportion of non-specialists increased at the invaded sites, which is obvious in this situation. The data on the shift of trophic groups as a result of plant invasion correspond to those of HARTLEY et al. (2004) on the invasion of Chinese tallow tree (Triadica sebifera, synonym Sapium sebiferum) in Texas and those of KAPPES et al. (2007) on the giant knotweed invasion with regard to different 
groups of arthropods. The relative proportions of cosmopolitan, semicosmopolitan and Holartic mites increased in Fallopia stands. This is also a strong indication of negative changes in the environmental conditions in the soil system, which influence saprophagous oribatid mites.

Yet, the proportion of parthenogenetic mites was significantly lower within the Fallopia stands. Recent literature has focused on reproductive modes as a possible explanation for the distribution patterns of oribatid mites (CIANCIOLO \& NoRTON 2006; SCHNEIDER et al. 2007). According to the "general-purpose genotype" theory, disturbances may increase the proportion of species and individuals that reproduce via thelytoky, while species that are characterized by the sexual mode of reproduction benefit from constant conditions (SCHAEFER et al. 2006). If the stand totally invaded by Fallopia is considered to be a less stable habitat than an area free of the invader, then a higher proportion of parthenogenetic oribatid mites can be expected in an invaded area. The results do not support the above explanation for distribution patterns of oribatid mites, as the proportion of parthenogenetic mites at site I was much lower than at site III. Scheu \& Drossel (2007) presented a model which explains the dominance of sexuality or parthenogenesis in a given soil-related substrate by the nature and abundance of resources. One of the key features of the model is that sexual reproduction sets in when resources become scarce. It seems that this trait well explains the observed habitat-reproductive-mode relationships in the above study.

Mites are becoming increasingly used as bioindicators of soil soil disturbance. Oribatid species and their communities may reflect the impact of various human activities (for a full list of references, see SkUBAŁA 2004). They offer also several advantages for assessing the impact of invasive weeds. Oribatids reach high densities even in highly simplified habitats with plant invaders. In comparison with some macroinvertebrates, they are easily sampled and can be collected in all seasons. Furthermore, oribatids are in close contact with defined microenvironmental conditions and are directly exposed to toxicants, by contact or direct ingestion of soil particles and soil water. Other apparent advantages seem to be a great deal of diversity in both taxonomy and functionality within oribatids collected from a small area. However, there are also negative aspects of the use of oribatids in bioindication, e.g. their small size, difficulties in identification, or some difficulties in standardising their sampling and extraction.

\section{CONCLUSIONS}

1. A link between the replacement of native plant species by the knotweed (Fallopia) and species richness of oribatid fauna was observed. This successful exotic invasive species has a moderate influence on species richness and a profound effect on soil oribatid mite community composition.

2. The shift of groups with different habitat specificity (e.g. high proportion of eurytopic mites at invaded sites), ecomorphological groups (e.g. low proportion of litter-dwelling mites at invaded sites), and zoogeographical groups (e.g. high proportion of mites with broad geographical distribution at invaded sites) proves the radical negative change of environmental conditions for soil oribatid mites as a result of Fallopia invasion. 
3. Trophic groups of oribatids reacted differently to Fallopia invasion. The reaction of macrophytophagous mites suggests that the plant material of Fallopia is much less palatable for oribatid mites than that produced by native plants.

4. The increase in sexually reproducing oribatid mites at invaded sites suggests that this way of reproduction is preferable when resources are in shortage.

\section{REFERENCES}

Ashton I. W., Hyatt L. A., Howe K. M., Gurevitch J., Lerdau M. T. 2005. Invasive species accelerate decomposition and litter nitrogen loss in a mixed deciduous forest. Ecol. Appl. 15: $1263-1272$.

Bardgett R. D., Wardle D. A., Yeates G. W. 1998. Linking above-ground and below-ground interactions: how plant responses to foliar herbivory influence soil organisms. Soil Biol. Biochem. 30: $1867-1878$.

BeErling D. J., Dawah H. A. 1993. Abundance and diversity of invertebrates associated with Fallopia japonica (Houtt. Ronse Decraene) and Impatiens glandulifera (Royle): two alien plant species in the British Isles. The Entomologist 112: 127-139.

Belnap J., Phillips S. L. 2001. Soil biota in an ungrazed grassland: response to annual grass (Bromus tectorum) invasion. Ecol. Appl. 11: 1261-1275.

BorCARD D. 1994. Les Oribates des tourbiéres du Jura suisse (Acari, Oribatei). Faunistique VI. Oppioidea (Thyrisomidae), Hydrozetoidea, Cymbaeremoidea, Oribatuloidea (part.). Bull. Soc. entomol. suisse 67: 363-372.

Cianciolo J. M., Norton R. A. 2006. The ecological distribution of reproductive mode in oribatid mites, as related to biological complexity. Exp. Appl. Acarol. 40: 1-25.

Dassonville N., Domken S., Herpigny B., Poly F., Meerts P. 2010. Impact of Fallopia spp. on ecosystem functioning: Nitrogen and organic matter cycling and implicated soil biota. In: Science Facing Aliens. Proceedings of a scientific meeting on Invasive Alien Species, Brussels (Segers H., Branquart E., Eds), May 11th 2009, pp. 19-24, Belgian Biodiversity Platform.

EHRENFELD J. G. 2003. Effects of exotic plant invasions on soil nutrient cycling processes. Ecosystems 6: 503-523.

Gerber E., Krebs C., Murrell C., Moretti M., Rocklin R., Schaffner U. 2008. Exotic knotweeds (Fallopia spp.) negatively affect native plant and invertebrate assemblages in European riparian habitats. Biol. Cons. 141: 646-654.

Hartley M. K., DeWalt S., Rogers W. E., Siemann E. 2004. Characterization of arthropod assemblage supported by the Chinese Tallow tree (Sapium sebiferum). Tex. J. Sci. 56: 369-82.

Kappes H., Lay R., Topp W. 2007. Changes in different trophic levels of litter-dwelling macrofauna associated with giant knotweed invasion. Ecosystems 2: 734-744. doi:10.1007/s10021-0079052-9.

Koutika L-S., Rainey H. J. Dassonville N. 2011. Impacts of Solidago gigantea, Prunus serotina, Heracleum mantegazzianum and Fallopia japonica invasions on ecosystems. Appl. Ecol. Environ. Res. 91: 73-83.

Koutika L.-S., Vanderhoeven S., Chapuis-Lardy L., Dassonville N., Meerts P. 2007. Assessment of changes in soil organic matter following invasion by exotic plant species. Biol. Fert. Soils 44: 331-341.

Krivolutsky D. A. 1995. Oribatid mites. Morphology, development, phylogeny, ecology, methods of study, model species Nothrus palustris C.L. Koch, 1839. Moscow, Nauka Publishers (in Russian). 
Luxton M. 1972. Studies on the oribatid mites of a Danish beech wood soil. I. Nutritional biology. Pedobiologia 12: 434-463.

Nicolini F., Topp W. 2005. Soil properties in plantations of sessile oak (Quercus petraea) and red oak (Quercus rubra) in reclaimed lignite open-cast mines of the Rhineland. Geoderma 129: $65-72$.

Norton R. A., Kethley J. B., Johnston D. E., O’Connor B. M. 1993. Phylogenetic perspectives on genetic systems and reproductive modes of mites. In: Evolution and diversity of sex ratio in insects and mites (Wrensch D., Ebbert M., Eds), pp. 8-99, Chapman and Hall, USA.

Porazinska D., Bardgett R. D., Blaauw M. B., Hunt H. W., Parsons A. N., Seastedt T. R., Wall D. H. 2003. Relationships at the aboveground-belowground interface: Plants, soil biota, and soil processes. Ecol. Monogr. 73: 377-395.

Pritekel C., Whittemore-Olson A., Snow N., Moore J. C. 2006. Impacts from invasive plant species and their control on the plant community and belowground ecosystem at Rocky Mountain National Park, USA. Appl. Soil Ecol. 32: 132-141.

Schaefer I., Domes K., Heethoff M., Schneider K., Schön I., Scheu S., Norton R. A., Maraun M. 2006. No evidence for the 'Meselson effect' in parthenogenetic oribatid mites. J. Evolution. Biol. 19: 184-193.

Schatz H. 1983. Catalogus Fauna Austriae, Teil IXi U. - Ordn.: Oribatei, Hornmilben. Vienna: Österreichischen, Akademie der Wissenschaften (in German).

Scheu S., Drossel B. 2007. Sexual reproduction prevails in a world of structured resources in short supply. Proc. R. Soc. B. 274: 1225-1231. doi: 10.1098/rspb.2007.0040.

Schneider K., Scheu S., Maraun M. 2007. Microarthropod density and diversity respond little to spatial isolation. Basic Appl. Ecol. 8: 26-35.

SkUBAŁA P. 2004. Colonization and development of oribatid mite communities (Acari: Oribatida) on post-industrial dumps. Wyd. Uniwersytetu Śląskiego, Katowice

Skubata P., Mierny A. 2009. Invasive Reynoutria taxa as a contaminant of soil. Does it reduce abundance and diversity of microarthropods and damage soil habitat? Pestycydy/Pesticides 1-4: 57-62.

St. John M. G., Wall D. H., Hunt H. W. 2006. Are soil mite assemblages structured by the identity of native and invasive alien grasses? Ecology 87: 1314-1324.

Subias L. S. 2004. Listado sistemático, sinonímico y biogeográfico de los Ácaros Oribátidos (Acariformes, Oribatida) del mundo (1758-2002). Graellsia 60 (in Spanish with English summary). Updated in February 2011.http://www.ucm.es/info/zoo/Artropodos/Catalogo.pdf; Accessed 30/05/11

Topp W., Kappes H., Rogers F. 2008. Response of ground-dwelling beetle (Coleoptera) assemblages to giant knotweed (Reynoutria spp.) invasion. Biol. Invasions 10: 381-390.

Wardle D. A., Bonner K. I., Barker G. M., Yeates G. W., Nicholson K. S., Bardgett R. D., Watson R. N., Ghani A. 1999. Plant removals in perennial grassland: vegetation dynamics, decomposers, soil biodiversity, and ecosystem properties. Ecol. Monogr. 69: 535-568.

Wardle D. A., Nicholson K. S., Rahman A. 1995. Ecological effects of the invasive weed species Senecio jacobaea L. (ragwort) in a New Zealand pasture. Agric. Ecosyst. Environ. 56: $19-28$.

Weigmann G. 2006. Hornmilben (Oribatida). Die Tierwelt Deutschlands, 76. Teil. Goecke \& Evers, Keltern (in German). 
Appendix I. List of oribatid species found at 3 sites with different coverage of Fallopia sachalinensis in mixed forest, with basic information on ecology, geographical distribution, and reproduction of the species

\begin{tabular}{|c|c|c|c|c|c|c|}
\hline Species & $\mathrm{Hab}$ & Ecol & $\operatorname{Tr}$ & $\mathrm{Zg}$ & $\mathrm{R}$ & Site \\
\hline Hypochthonius rufulus rufulus Koch, 1835 [Hruf] & $\mathrm{E}$ & Ns & Mic & $\mathrm{SC}$ & $\mathrm{P}$ & all \\
\hline Acrotritia duplicata (Grandjean, 1953) [Adup] & $\mathrm{F}$ & $\mathrm{L}$ & Mac & $\mathrm{P}$ & $\mathrm{P}$ & all \\
\hline $\begin{array}{l}\text { Euphthiracarus (E.) cribrarius cribrarius (Berlese, } \\
\text { 1904) }\end{array}$ & $\mathrm{F}$ & $\mathrm{L}$ & Mac & $\mathrm{H}$ & $\mathrm{S}$ & I \\
\hline Phthiracarus $(P$.$) compressus Jacot, 1930$ & $\mathrm{~F}$ & $\mathrm{Sf}$ & Mac & $\mathrm{H}$ & $\mathrm{S}$ & II \\
\hline Phthiracarus (P.) longulus (Koch, 1841) & $\mathrm{F}$ & Sf & Mac & $\mathrm{H}$ & $\mathrm{S}$ & I \\
\hline $\begin{array}{l}\text { Phthiracarus (Archiphthiracarus) anonymus } \\
\text { Grandjean, } 1933\end{array}$ & $\mathrm{~F}$ & Sf & Mac & $\mathrm{P}$ & S & all \\
\hline $\begin{array}{l}\text { Phthiracarus (Archiphthiracarus) globosus (Koch, } \\
\text { 1841) }\end{array}$ & $\mathrm{F}$ & Sf & Mac & $\mathrm{H}$ & S & II \\
\hline $\begin{array}{l}\text { Phthiracarus (Archiphthiracarus) occultus Niedbała, } \\
\quad 1981\end{array}$ & $?$ & Sf & Mac & $\mathrm{E}$ & $\mathrm{S}$ & I, II \\
\hline Nothrus pratensis Sellnick, 1928 & $?$ & $\mathrm{~L}$ & Pan & $\mathrm{H}$ & $P$ & II, III \\
\hline Nothrus silvestris Nicolet, 1855 [Nsil] & $\mathrm{E}$ & $\mathrm{L}$ & Pan & $\mathrm{H}$ & $\mathrm{P}$ & all \\
\hline $\begin{array}{l}\text { Heminothrus (Platynothrus) peltifer peltifer (Koch, } \\
\text { 1839) }\end{array}$ & $\mathrm{F}$ & $\mathrm{L}$ & Pan & $\mathrm{SC}$ & $\mathrm{P}$ & all \\
\hline Nanhermannia $(N$.$) nana (Nicolet, 1855)$ & $\mathrm{F}$ & $\mathrm{L}$ & Pan & $\mathrm{SC}$ & $\mathrm{P}$ & II \\
\hline Metabelba (Parametabelba) italica (Sellnick, 1931) & $?$ & Sf & Mic & E & $\mathrm{S}$ & I, II \\
\hline Damaeus (Adamaeus) onustus Koch, 1841 & $\mathrm{~F}$ & Sf & Mic & $\mathrm{P}$ & S & all \\
\hline Damaeus $(D$.$) riparius Nicolet, 1855$ & $\mathrm{~F}$ & Sf & Mic & $P$ & $\mathrm{~S}$ & I \\
\hline $\begin{array}{l}\text { Damaeus (Kunstidamaeus) tecticola tecticola } \\
\quad \text { Michael, } 1888\end{array}$ & $?$ & Sf & Mic & $\mathrm{E}$ & $\mathrm{S}$ & II \\
\hline $\begin{array}{l}\text { Damaeus (Spatiodamaeus) boreus Bulanova- } \\
\text { Zachvatkina, } 1957\end{array}$ & $?$ & $\mathrm{Sf}$ & Mic & $\mathrm{E}$ & $\mathrm{S}$ & I, III \\
\hline $\begin{array}{l}\text { Damaeus (Spatiodamaeus) fageti Bulanova- } \\
\text { Zachvatkina, } 1957\end{array}$ & $\mathrm{~F}$ & Sf & Mic & $\mathrm{E}$ & $\mathrm{S}$ & III \\
\hline Metabelba (M.) pulverulenta (Koch, 1839) [Mpul] & $\mathrm{F}$ & Sf & Mic & $\mathrm{H}$ & $\mathrm{S}$ & all \\
\hline Cepheus dentatus (Michael, 1888) & $\mathrm{F}$ & Sf & Mac & $\mathrm{P}$ & $\mathrm{S}$ & III \\
\hline Ceratoppia bipilis bipilis (Hermann, 1804) & $\mathrm{F}$ & Sf & Pan & $\mathrm{H}$ & $\mathrm{S}$ & all \\
\hline Ceratoppia quadridentata (Haller, 1882) & $\mathrm{E}$ & Sf & Mic & $\mathrm{H}$ & $\mathrm{S}$ & all \\
\hline Adoristes (A.) ovatus ovatus (Koch, 1839) & $\mathrm{F}$ & Sf & Pan & $\mathrm{P}$ & $\mathrm{S}$ & II, III \\
\hline Eremaeus hepaticus hepaticus Koch, 1835 & $\mathrm{~F}$ & Sf & Mic & $\mathrm{H}$ & $\mathrm{S}$ & I, II \\
\hline Eueremaeus oblongus (Koch, 1835) & $\mathrm{F}$ & Sf & Mic & $\mathrm{H}$ & $\mathrm{S}$ & II, III \\
\hline Ctenobelba (C.) pectinigera (Berlese, 1908) & $\mathrm{E}$ & S & $?$ & $\mathrm{E}$ & $\mathrm{S}$ & II \\
\hline Pantelozetes paolii (Oudemans, 1913) & E & Ns & Pan & $\mathrm{H}$ & $\mathrm{S}$ & all \\
\hline $\begin{array}{l}\text { Autogneta }(\text { A.) longilamellata longilamellata } \\
\text { (Michael, 1885) }\end{array}$ & $\mathrm{F}$ & $\mathrm{S}$ & Mic & $\mathrm{H}$ & $\mathrm{S}$ & II \\
\hline Conchogneta willmanni willmanni (Dyrdowska, 1929) & $\mathrm{F}$ & Sf & Pan & $\mathrm{P}$ & $\mathrm{S}$ & all \\
\hline Banksinoma lanceolata lanceolata (Michael, 1885) & $\mathrm{E}$ & Ns & Pan & $\mathrm{P}$ & $\mathrm{S}$ & II \\
\hline Belba (B.) patelloides (Michael, 1888) & $\mathrm{F}$ & Sf & Mic & $\mathrm{P}$ & $\mathrm{S}$ & all \\
\hline Multioppia (M.) glabra (Mihelčič, 1955) & $\mathrm{E}$ & S & Mic & $\mathrm{E}$ & $\mathrm{S}$ & II, III \\
\hline Ramusella (R.) clavipectinata (Michael, 1885) & E & S & Mic & $\mathrm{SC}$ & $\mathrm{S}$ & III \\
\hline
\end{tabular}




\begin{tabular}{|c|c|c|c|c|c|c|}
\hline Ramusella (Insculptoppia) furcata (Willmann, 1928) & F & $\mathrm{S}$ & Mic & $\mathrm{E}$ & $\mathrm{S}$ & II \\
\hline Ramusella (Insculptoppia) insculpta (Paoli, 1908) & $\mathrm{E}$ & $\mathrm{S}$ & Mic & $\mathrm{P}$ & $\mathrm{S}$ & II \\
\hline Rhinoppia subpectinata (Oudemans, 1900) [Rsub] & $\mathrm{E}$ & $\mathrm{S}$ & Mic & $\mathrm{H}$ & $\mathrm{S}$ & all \\
\hline Oppiella (O.) nova nova (Oudemans, 1902) & $\mathrm{E}$ & $\mathrm{S}$ & Mic & $\mathrm{C}$ & $\mathrm{P}$ & II, III \\
\hline Suctobelbella (S.) messneri Moritz, 1971 & $?$ & $\mathrm{~S}$ & Mic & E & $\mathrm{P}$ & II \\
\hline $\begin{array}{l}\text { Suctobelbella (Flagrosuctobelba) alloenasuta Moritz, } \\
1971 \text { (S.) }\end{array}$ & $\mathrm{F}$ & $\mathrm{S}$ & Mic & $\mathrm{H}$ & $\mathrm{P}$ & III \\
\hline Dolicheremaeus sp. Jacot, 1938 & ? & $\mathrm{S}$ & Mic & $?$ & $\mathrm{~S}$ & I \\
\hline Carabodes (C.) areolatus Berlese, 1916 & $\mathrm{~F}$ & $\mathrm{Sf}$ & Pan & $\mathrm{P}$ & $\mathrm{S}$ & II \\
\hline Carabodes (C.) femoralis (Nicolet, 1855) & $\mathrm{F}$ & Sf & Pan & $\mathrm{P}$ & $\mathrm{S}$ & all \\
\hline Carabodes (C.) labyrinthicus (Michael, 1879) & $\mathrm{F}$ & Sf & Mac & $\mathrm{H}$ & $\mathrm{S}$ & all \\
\hline Carabodes (C.) ornatus Štorkán, 1925 & $\mathrm{~F}$ & Sf & Pan & $\mathrm{P}$ & $\mathrm{S}$ & II \\
\hline Tectocepheus alatus Berlese, 1913 & $\mathrm{O}$ & Ns & Mic & $\mathrm{P}$ & $\mathrm{P}$ & I, III \\
\hline Tectocepheus velatus velatus (Michael, 1880) & $\mathrm{E}$ & Ns & Mic & $\mathrm{C}$ & $\mathrm{P}$ & II, III \\
\hline Cymbaeremaeus cymba (Nicolet, 1855) & $\mathrm{F}$ & Sf & Mic & $\mathrm{P}$ & $\mathrm{S}$ & III \\
\hline Eupelops major major (Hull, 1914) & $\mathrm{F}(?)$ & Sf & Pan & $\mathrm{H}$ & $\mathrm{S}$ & III \\
\hline Eupelops torulosus (Koch, 1839) & $\mathrm{F}$ & Sf & Pan & $\mathrm{P}$ & $\mathrm{S}$ & II, III \\
\hline $\begin{array}{l}\text { Achipteria (A.) coleoptrata coleoptrata (Linnaeus, } \\
\text { 1758) }\end{array}$ & E & Sf & Pan & $\mathrm{H}$ & $\mathrm{S}$ & all \\
\hline Oribatella $(O$.$) calcarata ($ Koch, 1835) & $\mathrm{F}$ & $\mathrm{Sf}$ & Pan & $\mathrm{H}$ & $\mathrm{S}$ & all \\
\hline Ceratozetes sellnicki Rajski, 1958 & $\mathrm{E}$ & Sf & Pan & $\mathrm{H}$ & $\mathrm{S}$ & III \\
\hline Ceratozetella $(C$.$) cisalpina (Berlese, 1908)$ & $?$ & Sf & Pan & $\mathrm{H}$ & $\mathrm{S}$ & I \\
\hline Ceratozetes $($ C.) gracilis (Michael, 1884) [Cgra] & $\mathrm{E}$ & Sf & Pan & $\mathrm{C}$ & $\mathrm{S}$ & all \\
\hline Ceratozetes (C.) mediocris Berlese, 1908 & $\mathrm{~F}$ & Sf & Pan & $\mathrm{SC}$ & $\mathrm{S}$ & I, III \\
\hline Ceratozetes (C.) peritus Grandjean, 1951 & $\mathrm{E}$ & Sf & Pan & $\mathrm{H}$ & $\mathrm{S}$ & III \\
\hline Euzetes globulus (Nicolet, 1855) & $\mathrm{F}$ & $\mathrm{Sf}$ & Pan & $\mathrm{P}$ & $\mathrm{S}$ & II \\
\hline Sphaerozetes (S.) piriformis (Nicolet, 1855) & $\mathrm{F}$ & Sf & Pan & $\mathrm{P}$ & $\mathrm{S}$ & II, III \\
\hline Chamobates $(C$.$) pusillus (Berlese, 1895)$ & $\mathrm{F}$ & Ns & Mic & $\mathrm{P}$ & $\mathrm{S}$ & all \\
\hline $\begin{array}{l}\text { Chamobates (Xiphobates) voigtsi (Oudemans, 1902) } \\
\text { [Cvoi] }\end{array}$ & $\mathrm{F}$ & Ns & Pan & $\mathrm{P}$ & $\mathrm{S}$ & all \\
\hline Minunthozetes (M.) semirufus (Koch, 1841) & $\mathrm{E}$ & $\mathrm{S}$ & Mic & $\mathrm{P}$ & $\mathrm{S}$ & I \\
\hline Punctoribates (P.) punctum (Koch, 1839) & $\mathrm{O}$ & $\mathrm{S}$ & Pan & $\mathrm{SC}$ & $\mathrm{S}$ & all \\
\hline Oribatula $(O$.$) tibialis tibialis (Nicolet, 1855) [Otib]$ & E & Ns & Pan & $\mathrm{H}$ & $\mathrm{S}$ & all \\
\hline Hemileius (H.) initialis (Berlese, 1908) [Hini] & E & Ns & Pan & $\mathrm{SC}$ & $\mathrm{S}$ & all \\
\hline Liebstadia (L.) pannonica (Willmann, 1951) & $\mathrm{O}$ & Sf & Pan & $\mathrm{H}$ & $\mathrm{S}$ & III \\
\hline Scheloribates (S.) pallidulus (Koch, 1841) & $\mathrm{O}$ & Sf & Pan & $\mathrm{C}$ & $\mathrm{S}$ & I, III \\
\hline Acrogalumna longipluma longipluma (Berlese, 1904) & E & Sf & Pan & $\mathrm{SC}$ & $\mathrm{S}$ & II, III \\
\hline Galumna (G.) obvia (Berlese, 1914) & $\mathrm{O}$ & Sf & Pan & $\mathrm{SC}$ & $\mathrm{S}$ & all \\
\hline Pergalumna nervosa nervosa (Berlese, 1914) [Pner] & $\mathrm{F}$ & Sf & Pan & $\mathrm{H}$ & $\mathrm{S}$ & all \\
\hline Pilogalumna crassiclava crassiclava (Berlese, 1914) & ? & Sf & Pan & $\mathrm{P}$ & $\mathrm{S}$ & II \\
\hline
\end{tabular}

$\mathbf{H a b}=$ habitat specificity: $\mathrm{E}=$ eurytopic; $\mathrm{F}$ = forest; $\mathrm{O}=$ open habitat; ? = unknown: Ecol = ecomorphological group: $\mathrm{SF}=$ surface-dwelling; $\mathrm{L}=$ litter-dwelling; $\mathrm{S}==$ soil-dwelling; $\mathrm{Ns}=$ non-specialized; $\mathbf{T r}=$ trophic group: Pan = panphytophagous; Mic = microphytophagous; Mac = macrophytophagous; $?=$ unknown; $\mathbf{Z g}=$ zoogeographical group: $\mathrm{C}=$ cosmopolitan; $\mathrm{SC}=$ semicosmopolitan; $\mathrm{H}=$ Holarctic; $\mathrm{P}=$ Palaearctic $; \mathrm{E}=$ European; $\mathbf{R}=$ reproduction: $\mathrm{S}=$ sexual; $\mathrm{P}=$ parthenogenetic. 